\title{
Assessment of absorption ability of air pollutant on forest in Gongju-city
}

\author{
Ji-Young Eom, Seok-Hee Jeong and Jae-Seok Lee ${ }^{*}$ (iD
}

\begin{abstract}
Background: Some researchers have attempted to evaluate the ecological function of various additional services, away from the main point of view on the timber production of Korean forests. However, basic data, evaluation models, or studies on the absorption of air pollutants related to major plant communities in Korea are very rare. Therefore, we evaluated the functional value of the forest ecosystem in Gongju-city. Plantation manual for air purification, supplied from the Ministry of Environment in Japan, was referred to process and method for assessment of air pollutant absorption.

Results: Gross primary production was calculated about average $18.2 \mathrm{t} / \mathrm{ha} / \mathrm{year}$. It was a relatively low value in forests mixed with deciduous broad and evergreen coniferous compared to pure coniferous forest. Net primary production was the highest value in deciduous coniferous and was the lowest value in mixed forest with deciduous broad and evergreen broad. And the mean sequestration amount of each air pollutant per unit area per year assessed from gross primary production and concentration of gas was the highest with $75.81 \mathrm{~kg} / \mathrm{ha} / \mathrm{year}$ in $\mathrm{O}_{3}$ and was $16.87 \mathrm{and} 6.04 \mathrm{~kg} /$ ha/year in $\mathrm{NO}_{2}$ and $\mathrm{SO}_{2}$, respectively. In addition, total amounts of $\mathrm{CO}_{2}$ absorption and $\mathrm{O}_{2}$ production were $716,045 \mathrm{t}$ $\mathrm{CO}_{2} /$ year and 520,760 $\mathrm{t} \mathrm{O}_{2} /$ year in all forest vegetation in Gongju-city.

Conclusions: In this study, we evaluated the absorption ability of air pollutant in 2014 on forest in Gongju-city area. Gongju-city has the broad mountain area about 70.3\%, and area of deciduous broad leaves forest was established the broadest with $47.4 \%$ of genus Quercus. Pg was calculated about average $18.2 \mathrm{t} /$ ha/year. The mean sequestration amount of each air pollutant per unit area per year assessed from $\mathrm{Pg}$ and $\mathrm{C}_{\text {gas }}$ was the highest with $75.81 \mathrm{~kg} / \mathrm{ha} / \mathrm{year}$ in $\mathrm{O}_{3}$ and were 16.87 and $6.04 \mathrm{~kg} / \mathrm{ha} /$ year in $\mathrm{NO}_{2}$ and $\mathrm{SO}_{2}$, respectively. Absorption rates of $\mathrm{O}_{3}, \mathrm{NO}_{2}$, and $\mathrm{SO}_{2}$ were the highest in evergreen coniferous forest about $14.87 \mathrm{kgO}_{3} / \mathrm{ha} /$ year, $3.30 \mathrm{kgNO}_{2} / \mathrm{ha} /$ year, $1.18 \mathrm{kgSO} \mathrm{N}_{2} / \mathrm{ha} /$ year, and the lowest were 5 . $95 \mathrm{kgO}_{3} / \mathrm{ha} /$ year, $1.32 \mathrm{kgNO}_{2} / \mathrm{ha}$ /year, and $0.47 \mathrm{kgSO}_{2} / \mathrm{ha} /$ year in deciduous broad forest. In conclusion, it was evaluated that Japanese model is suitable for estimating air pollutants in Japan to Korean vegetation. However, in Korea, there is a very limited basic data needed to assess the ability of forests to absorption of air pollutants. In this study, the accuracy of a calculated value is not high because the basic data of trees with similar life form are used in evaluation.
\end{abstract}

Keywords: Ecosystem service, Gross primary production, Net primary production, Air pollutant, $\mathrm{CO}_{2}$ absorption, $\mathrm{O}_{2}$ production

\section{Background}

Ecosystem supplies various services to human through progressing of basic ecological function related to energy flow and material cycle. These services include various ecosystem products such as basic supplement from food and water to water quality and climate controlling (Costanza et al. 1997). On these ecosystem services, Millennium Ecosystem Assessment (2005) submitted typical

\footnotetext{
* Correspondence: jaeseok@konkuk.ac.kr

Department of Biological Science, Konkuk University, 05029 Seoul, Republic of Korea
}

(c) The Author(s). 2017 Open Access This article is distributed under the terms of the Creative Commons Attribution 4.0 International License (http://creativecommons.org/licenses/by/4.0/), which permits unrestricted use, distribution, and reproduction in any medium, provided you give appropriate credit to the original author(s) and the source, provide a link to the Creative Commons license, and indicate if changes were made. The Creative Commons Public Domain Dedication waiver (http://creativecommons.org/publicdomain/zero/1.0/) applies to the data made available in this article, unless otherwise stated. ing Biodiversity Conservation in Dynamic Ecosystems project; Vandewalle et al. 2009) is possible to calculate unit of nation and area in Europe using information about ecosystem service (supply, control, culture, support), GUMBO (Global Unified Model of the Biosphere; Boumans et al. 2002) is possible to integrate assessment about multi-scale, and InVEST (Integrated Valuation of Environmental Services and Tradeoffs; Nelson et al. 2009) can evaluate with territorial unit. 
Forest was functionally divided to timber production, storage of water resource, protection of forest disaster, forest resting, and others from 1970 in Japan. And they also are trying to make developed evaluation of fine forest function using GIS tool (Kweon et al. 2008). Also, function of various ecosystem services is increasing, not providing simple green area in Korea (Kweon 2008; Shu et al. 2006). According to the data of the National Statistical Office in 2015, about $64 \%$ of the total land area in South Korea is forested and it resulted from the sustainable and political promotion and management by the government from 1970s. In present, forest reached a level of mature not timber production but having the various ecological functions in Korea. Some studies tried to evaluate the ecological functions of various additional services away from primary view of point with timber production in Korean forest (Kweon 2008; Shu et al. 2006; Lee et al. 2010; Kim et al. 2015; Song 2015).

The functions of forest ecosystem are divided to economical function of trading parts in market such as timber, pulp, fuel, mushroom, and medicine and to public function of non-trading parts such as storage of water resource, improving of air quality, protection of forest disaster, maintaining of life environment, and forest rest (Kim et al. 2012; Korean Forest Affair 2000; National forest research, 2016). These functions can be evaluated with market value as price decision by demand and supply of forest product about timber. In various forest functions, maintaining of life environment includes abilities such as absorption of greenhouse gas, improving of air quality, production of oxygen, and depress of heat island. And improving of air quality is highly noticed under the high increasing of concentrations of $\mathrm{SO}_{2}$ and $\mathrm{O}_{3}$, particular material resulted from the proceeding of industrialization in China and East-south Asia.

Promotion of air quality by plant is mainly performed under the processing of plant photosynthesis. In opening status of stomata, $\mathrm{CO}_{2}$ and $\mathrm{H}_{2} \mathrm{O}$ are transported in and out of the plant body, and then, gases materials as $\mathrm{SO}_{2}$ and $\mathrm{NO}_{2}$ are also flowed from atmosphere in plant with diffusion due to difference of concentration. Air pollutants flowing into plant body are flowed by diffusible force under the uninfluential low range to basic physiological process such as transpiration and photosynthesis or to direct influence to leaf.

Therefore, the amount of air pollutant absorption can be estimated from relationship between absorptions of $\mathrm{CO}_{2}$ and air pollutant that pollutant absorption rate is high in a lot of photosynthesis status. Ultimately, flowing rate of air pollutant into plant is highly related with difference of concentration between interior and exterior of plant and opening status of stoma of plant. Estimation of air pollutant absorption in plant community can be calculated from ratios between absorption rates of $\mathrm{CO}_{2}$ and air pollutants. However, it is very rare that basic data, assessment model, or study of air pollutant absorption is related to major plant communities in Korea.

In this study, we tried to evaluate functional value of forest ecosystem on regional area in Gongju-city using the Japan assessment model (Japan Environmental affair, 2014; Sugahara and Aiga 1987). Japan is very similar to Korea in environments of forest, air pollutants, way of life, etc. Especially, forest type, life form, and community structure composed with Pinus densiflora, Quercus mongolica, Quercus acutissima, Quercus serrata, etc., are very similar in Korean forest. For this reason, it was judged that the applicability of the model was high.

\section{Methods}

\section{Site description}

Gongju-city is a small and medium-sized city, located in central part in Chungcheongnamdo province, and occupies a basin surrounded by Charyeong Mountains in the northwest and Mt. Gyeryong in the southeast and the population is around 113,000 . The area is about $940,393 \mathrm{~km}^{2}$, and the areas of field, rice field, and forest are about $60,934,116,426$, and $653,880 \mathrm{~km}^{2}$, respectively. Annual mean air temperature is about $11.8{ }^{\circ} \mathrm{C}$; air temperature is $24.7{ }^{\circ} \mathrm{C}$ in high-temperature summer season, averaging about $-0.9^{\circ} \mathrm{C}$ in low temperature season (http://www.gongju-city.go.kr/).

\section{Air pollutant}

Air pollutants were stipulated air pollutant included in particle material and special air pollutant materials such as $\mathrm{Cd}$ in air Environmental Conservation Act. In this study, we selected three pollutants $\mathrm{SO}_{2}, \mathrm{NO}_{2}$, and $\mathrm{O}_{3}$ that are causative agent having various and strong influences on human and its surrounding environment. Also, concentrations of these pollutants are on the increase through rapid industrial development and highly increasing of automobile.

\section{Calculation of amount of pollutant absorption}

Basically, Plantation manual for air purification (In Japanese, Environmental Restoration and Conservation Agency 2014), supplied from the Ministry of Environment in Japan, was referred to the process and method for the assessment of air pollutant absorption. The process is composed of assessments of area of forest type, concentration of air pollutant, gross-primary production and net primary production, calculation of absorbed amount of air pollutant using correlation functional model, and applying of forest period.

\section{Areas of forest type}

The area of forest types was collected from data base of Korean Forest Service (2016). Forests are classified into 
mainly three types: coniferous forests, deciduous forests, and mixed forests. Area in mixed forest area with broad and coniferous was calculated to half value in each total forest type.

\section{Concentration of air pollutant}

Concentrations of pollutant were collected in Sagokmyen, Gongju-city $\left(\mathrm{E} 127.03^{\circ}, \mathrm{N} 36.53^{\circ}\right)$, for assessing air pollutant absorption capacity. These data is supplied by Air Korea (http://www.airkorea.or.kr) in the Ministry of Environment.

However, it was used with average value from Mar. 1 to 10 for lack of data from Jan. 2014 to Feb. All values of pollutant concentration were converted from $\mathrm{ppm}$ to $\mu \mathrm{g} / \mathrm{cm}^{3}$ for using model function.

\section{Gross-primary production and net primary production}

Net primary production (Pn) was basically calculated from forest data collected in Chungcheongnamdo area. Because the ratio of Pn to gross-primary production (Pg) is very racking in Korea, the data of $\mathrm{Pn} / \mathrm{Pg}$ ratio internationally investigated in 1970s was used in this study (Japan Environmental affair, 2014).

Each Pn of the deciduous broad, evergreen coniferous, and deciduous coniferous forests were calculated by using data of natural $Q$. acutissima forest (E $127^{\circ} 11^{\prime}$ $\left.53^{\prime \prime} \sim 127^{\circ} 26^{\prime} 03^{\prime \prime}, \mathrm{N} 36^{\circ} 25^{\prime} 05^{\prime \prime} \sim 36^{\circ} 26^{\prime} 13^{\prime \prime}\right)$, Pinus koraiensis plantation forest (E $127^{\circ} 02^{\prime} 10^{\prime \prime} \sim 127^{\circ} 06^{\prime}$ $\left.07^{\prime \prime}, \mathrm{N} 36^{\circ} 35^{\prime} 58^{\prime \prime} \sim 36^{\circ} 36^{\prime} 58^{\prime \prime}\right)$, and Larix leptolepis plantation forest, respectively, studied by Kang (2010) in Gongju-city. Also, in the case of mixed forest with deciduous broad-leave and evergreen coniferous, a half of total value was used for each Pn and Pg, as following equations:

$$
\begin{aligned}
\mathrm{Pn} & =\frac{\text { Pn of } \mathrm{DB}}{2}+\frac{\mathrm{Pn} \text { of EGC }}{2} \\
\mathrm{Pg} & =\left(\frac{\text { Pn of } \mathrm{DB}}{2} \div \mathrm{Pn} / \mathrm{Pg} \text { of } \mathrm{DB}\right) \\
& +\left(\frac{\text { Pn of EGC }}{2} \div \mathrm{Pn} / \mathrm{Pg} \text { of EGC }\right)
\end{aligned}
$$

where $\mathrm{Pn}$ is the net primary production, $\mathrm{DB}$ is deciduous broad-leave, EGB is evergreen coniferous, and Pg is gross-primary production.

\section{Calculation of absorbed amount of air pollutant}

Absorbed amount of air pollutant was calculated using assessment model based on studied data of Miyake (1990) and Totsuka and Miyake (1991). This model was induced from interrelationship between gross primary production, net primary production, and absorbed amount of pollutant. We assumed that this model is very suitable for this study because vegetation, climate, and dwelling patterns of Japan are more similar to Korea than other nations such as Europe and America.

The relationship between absorption rate of pollutant gas and photosynthesis rate can be expressed as following Eq. (2):

$$
\begin{aligned}
& U_{\text {gas }}=K_{\text {gas }} \times C_{\text {gas }} \\
& U_{\mathrm{CO}_{2}}=K_{\mathrm{CO}_{2}} \times C_{\mathrm{CO}_{2}}
\end{aligned}
$$

where $U_{\text {gas }}$ is the absorption rate of pollutant gas, $U_{\mathrm{CO} 2}$ is the photosynthesis rate (absorption rate of $\mathrm{CO}_{2}$ ), $K_{\mathrm{gas}}$ is the leaf diffusion conductance of pollutant gas, $K_{\mathrm{CO} 2}$ is the diffusion conductance of $\mathrm{CO}_{2}, C_{\text {gas }}$ is the concentration of atmospheric pollutant gas $\left(\mu \mathrm{g} / \mathrm{cm}^{3}\right)$, and $C_{\mathrm{CO} 2}$ is the concentration of atmospheric $\mathrm{CO}_{2}\left(\mu \mathrm{g} / \mathrm{cm}^{3}\right)$.

From these relationships, the ratio of absorption rate of pollutant gas to photosynthesis rate is converted as following Eq. (3):

$$
\frac{U_{\text {gas }}}{U_{\mathrm{CO}_{2}}}=\frac{K_{\text {gas }}}{K_{\mathrm{CO}_{2}}} \times \frac{C_{\text {gas }}}{C_{\mathrm{CO}_{2}}}
$$

From function (2), the ratio of $K_{\text {gas }}$ to $K_{\mathrm{CO} 2}$ is calculated as following Eq. (4):

$$
\frac{K_{\mathrm{SO}_{2}}}{K_{\mathrm{CO}_{2}}}=8, \frac{K_{\mathrm{O}_{\mathrm{s}}}}{K_{\mathrm{CO}_{2}}}=5, \frac{K_{\mathrm{NO}_{2}}}{K_{\mathrm{CO}_{2}}}=6
$$

Also, because $\mathrm{CO}_{2}$ content ratio to glucose $\left(\mathrm{C}_{6} \mathrm{H}_{10} \mathrm{O}_{5}\right)$ is $1.63, P g$ is as following Eq. (5):

$$
U_{\mathrm{CO}_{2}}=1.63 \times \mathrm{Pg}
$$

In here, if atmospheric $\mathrm{CO}_{2}$ concentration is $390 \mathrm{ppm}$, it is converted to the value of $0.70 \mu \mathrm{g} / \mathrm{cm}^{3}$. Consequently, absorbed amounts of $\mathrm{SO}_{2}, \mathrm{O}_{3}$, and $\mathrm{NO}_{2}$ are simply arranged as following Eq. (6):

$$
\begin{aligned}
& U_{\mathrm{SO}_{2}}=18.6 \times C_{\mathrm{SO}_{2}} \times \mathrm{Pg} \\
& U_{\mathrm{O}_{\mathrm{s}}}=11.6 \times C_{\mathrm{O}_{\mathrm{s}}} \times \mathrm{Pg} \\
& U_{\mathrm{NO}_{2}}=13.9 \times C_{\mathrm{NO}_{2}} \times \mathrm{Pg}
\end{aligned}
$$

where $C_{\mathrm{SO} 2}, C_{\mathrm{O} 3}$, and $C_{\mathrm{NO} 2}$ are indicated concentrations of $\mathrm{SO}_{2}, \mathrm{O}_{3}$, and $\mathrm{NO}_{2}$, respectively. As above, absorbed amounts of $\mathrm{SO}_{2}, \mathrm{O}_{3}$, and $\mathrm{NO}_{2}$ are simply calculated from $\mathrm{Pn}$ and atmospheric concentration of each pollutant gas.

\section{$\mathrm{CO}_{2}$ absorption and $\mathrm{O}_{2}$ production}

Total amounts of $\mathrm{CO}_{2}$ absorption and $\mathrm{O}_{2}$ production were estimated from Pn data based on the study of Kim et al. (2010) in Gongju-city. The amounts of $\mathrm{CO}_{2}$ absorption and $\mathrm{O}_{2}$ production was calculated from ratio molecular weight of carbon and $\mathrm{O}_{2}$ to $\mathrm{Pn}$. 
Table 1 Area of each forest types in Gongju-city

\begin{tabular}{lll}
\hline Forest types & Area (ha) & Ratio (\%) \\
\hline DB & $14,007.7$ & 47.4 \\
EC & 3706.3 & 12.5 \\
DC & 77.4 & 0.3 \\
DEC & 32.0 & 0.1 \\
DBE & $11,568.3$ & 39.1 \\
DBC & 154.2 & 0.5 \\
EB & 18.1 & 0.1 \\
Total & $29,564.0$ & 100 \\
\hline
\end{tabular}

$D B$ deciduous broad, $E C$ Evergreen coniferous, $D C$ deciduous coniferous, $D E C$ deciduous \& evergreen coniferous, DBE deciduous broad \& evergreen coniferous, $D B C$ deciduous broad \& coniferous, $E B$ evergreen broad

\section{Results and discussion}

\section{Areas of each forest type}

Gongju-city have the broad mountain area about $70.3 \%$ which is a slightly higher value than about $64 \%$ that of Korea (Korea Forest Service 2016). And the deciduous broad-leaved forest, composed with Q. acutissima, Q. serrata, Q. variabilis, and Q. mongolica, was the broadest area with 14,008 ha of forest type in Gongju-city (Table 1). The evergreen coniferous forest mainly dominated with $P$. densiflora was established the second area with 3706 ha about 26\%. Lee et al. (2017) reported that forests in Korea peninsula are classified into three types: coniferous forests, deciduous forests, and mixed forests (Korea Forest Service 2016). In the deciduous forests that occupy $32 \%$ of the country, oak species in the genus Quercus are dominant such as Q. mongolica (Mongolian oak), Q. serrata (Korana oak), and Q. variabilis (Chinese cork oak). Most Quercus forests in South Korea are dominated by Q. mongolica in relatively higher mountain area (Yun et al. 2011) in areas of high altitude, whereas other Quercus species, such as Q. serrata and Q. variabilis, occur in areas of lower altitudes (Lee 2002).

In this study, also, the low altitude zone was broadly established with coniferous forest such as $P$. densiflora and $P$. rigida plantation and the deciduous broad-leaved forest of Quercus tree as Q. mongolica and Q. serrata was shown on habitat in the higher area than that in evergreen coniferous. Consequently, forest mixed with deciduous and coniferous was broadly established about 11,568 ha through board area between broad-leaved Quercus tree and coniferous tree of P. densiflora.

Deciduous coniferous forest such as Larix leptolepis (Japanese larch) and evergreen broad-leaved forests were very restricted about 77.0 and 18.0 ha, respectively, compared with evergreen coniferous forest and deciduous broad-leaved forest. This result related to climatic factor that as Larix leptolepis have the habitat in cooler area than that of $Q$. mongolica, and evergreen broad-leaved have warmer area than that of P. densiflora. Also, L. leptolepis in South-Korea is planted by government in 1970s.

From these, area of deciduous broad-leaved forest was $47.4 \%$ as purely dominated form of each Q. acutissima, $Q$. variabilis, and $Q$. mongolica. The mixed forest composed of deciduous broad and evergreen coniferous leaved forest was the second area with 11,568 ha $(39.1 \%)$. The evergreen coniferous forest dominated with $P$. densiflora was the third area with 3706 ha (12.5\%), 154.2 ha $(0.5 \%)$, 77.4 ha $(0.3 \%)$, and 18.1 ha $(0.1 \%)$ in forest areas mixed with deciduous broad-coniferous, deciduous coniferous, and evergreen coniferous, respectively.

\section{Concentration of pollutant}

Atmospheric concentration of $\mathrm{SO}_{2}$ and $\mathrm{NO}_{2}$ were seasonally fluctuated that these were especially increased in winter season when use of fossil is high under cold day

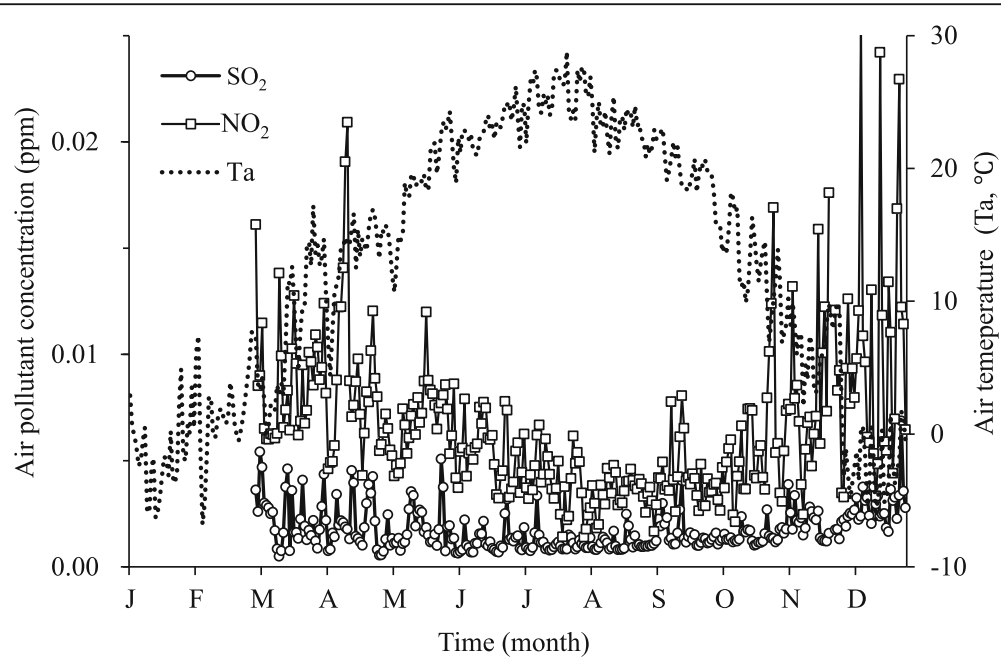

Fig. 1 Seasonal fluctuations of air pollutant concentration and temperature in Gongju-city (2014) 


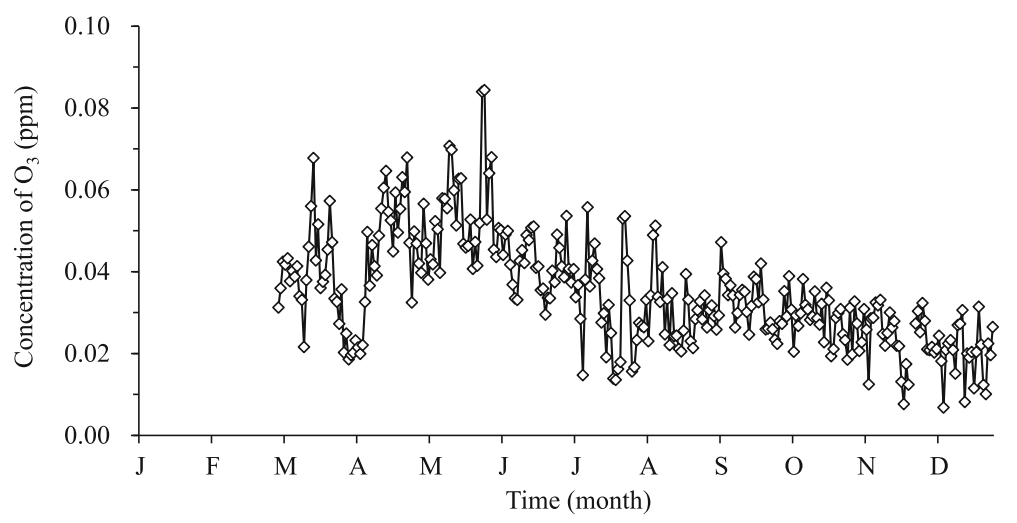

Fig. 2 Seasonal fluctuations of $\mathrm{O}_{3}$ in Gongju-city (2014). It was shown the highest in Jun and the lowest in December

and were decreased to very low concentration in summer season (Fig. 1). The lowest atmospheric concentration of $\mathrm{SO}_{2}$ was decreased to $0.0011 \mathrm{ppm}$ under average air temperatures of 25.4 and $23.8^{\circ} \mathrm{C}$ in Jul. and Aug., respectively, except for missing data period in Jan. and Feb. 2014. Also, the highest concentration showed $0.0028 \mathrm{ppm}$ under the air temperature of $-2.2{ }^{\circ} \mathrm{C}$ and precipitation of $29 \mathrm{~mm}$ in Dec. 2014. Also, atmospheric concentration of $\mathrm{NO}_{2}$ showed the lowest value of $0.0034 \mathrm{ppm}$ on average air temperature of $23.8{ }^{\circ} \mathrm{C}$ and precipitation of $211 \mathrm{~mm}$ in Aug (Fig. 1). However, it was increased to $0.01 \mathrm{ppm}$ in Dec. as high of 3.5 folds compared to average value. Average concentrations of $\mathrm{SO}_{2}$ and $\mathrm{NO}_{2}$ were shown as 0.0018 and $0.0065 \mathrm{ppm}$, respectively. Gongju-city is located in western-plot of thermoelectric power plant zone in Yongheung, Dangjin, Taean, Boryeng, and Seocheon. Therefore, atmospheric concentrations of $\mathrm{SO}_{2}$ and $\mathrm{NO}_{2}$ were highly related to increasing in winter season and decreasing in summer season in operating ratio of thermoelectric power plant.

Concentration of $\mathrm{O}_{3}$ was shown a high value on dry season in May and June and low on rainy season in July and August (Fig. 2). These results would have related that production of $\mathrm{O}_{3}$ is highly activated in low vapor pressures and high air temperature conditions (Griffin et al. 2002). Also, high atmospheric vapor condition is generally sustained during July and August in Korea because it belongs to rainy season so called Changma under the monsoon climate.

\section{$\mathrm{Pg}, \mathrm{Pn}$, and $\mathrm{Pn} / \mathrm{Pg}$}

Pg was evaluated average $18.0 \mathrm{t} / \mathrm{ha}$ /year ranged from 10.0 to $25.1 \mathrm{t} / \mathrm{ha} /$ year (Table 2). It was shown twenties of 25.1, 22.9 , and $20.8 \mathrm{t} / \mathrm{ha} /$ year in evergreen coniferous forest, mixed forest with deciduous and evergreen coniferous, and deciduous coniferous, respectively. Also, it was shown relatively low value of $17.6,15.8,15.4$, and 10.0 in forests mixed with deciduous broad and evergreen coniferous, evergreen broad, mixed with deciduous broad and coniferous, and deciduous broad, respectively, compared to pure coniferous forest. Ogawa (1992) reported about $41.0 \mathrm{t} / \mathrm{ha} /$ year of Pg in Saitama area, Japan. This is very high value compared with that of Gongju-city. The reason of these values is considered to be due to the high ratio of planted evergreen coniferous forest, $57.0 \mathrm{t} / \mathrm{ha} /$ year of $\mathrm{Pg}$, in that study area. However, Pn was $14.3 \mathrm{t} / \mathrm{ha} /$ year, which was almost the same. In this study, Pn was the highest value about $11.4 \mathrm{t} /$ ha/year in deciduous coniferous and was the lowest value about $5.5 \mathrm{t} /$ ha/year in mixed forest with deciduous broad and evergreen broad (Table 2). The ratio of Pn to Pg was shown 0.6 in deciduous broad, deciduous coniferous, mixed with deciduous broad and evergreen coniferous, and mixed with deciduous broad and coniferous and 0.4 in evergreen coniferous, mixed with deciduous and evergreen coniferous, and evergreen broad, respectively.

\section{Absorption rate of air pollutant per unit area}

The mean absorption rate of each air pollutant assessed from $\mathrm{Pg}$ and $C_{\text {gas }}$ was $75.81 \mathrm{~kg} \mathrm{O} /$ ha/year in $\mathrm{O}_{3}$ and was $16.87 \mathrm{~kg} \mathrm{NO}_{2} /$ ha/year and $6.04 \mathrm{~kg} \mathrm{SO}_{2} /$ ha/year, respectively. Absorption rates of $\mathrm{O}_{3}, \mathrm{NO}_{2}$, and $\mathrm{SO}_{2}$ were the highest in evergreen coniferous forest about $14.87 \mathrm{~kg}$ $\mathrm{O}_{3} /$ ha/year, $3.30 \mathrm{~kg} \mathrm{NO}_{2} /$ ha/year, and $1.18 \mathrm{~kg} \mathrm{SO} / \mathrm{ha} /$

Table 2 Gross primary production (Pg) and net primary production $(\mathrm{Pn})$ in Gongju-city

\begin{tabular}{llll}
\hline Forest types & $\mathrm{Pg}(\mathrm{t} / \mathrm{ha} /$ year $)$ & $\mathrm{Pn} / \mathrm{Pg}$ & $\mathrm{Pn}$ (t/ha/year) \\
\hline DB & 10.0 & 0.6 & 5.5 \\
EC & 25.1 & 0.4 & 8.8 \\
DC & 20.8 & 0.6 & 11.4 \\
DEC & 22.9 & $0.6 / 0.4$ & 10.1 \\
DBE & 17.6 & $0.6 / 0.4$ & 7.2 \\
DBC & 15.4 & 0.6 & 8.5 \\
EB & 15.8 & 0.4 & 5.5 \\
\hline
\end{tabular}

$D B$ deciduous broad, EC Evergreen coniferous, $D C$ deciduous coniferous, $D E C$ deciduous \& evergreen coniferous, $D B E$ deciduous broad \& evergreen coniferous, $D B C$ deciduous broad \& coniferous, $E B$ evergreen broad 
year, and the lowest were $5.95 \mathrm{~kg} \mathrm{O} /$ ha/year, $1.32 \mathrm{~kg}$ $\mathrm{NO}_{2} /$ ha/year, and $0.47 \mathrm{~kg} \mathrm{SO} /$ ha/year in deciduous broad forest (Table 3).

\section{Absorbed amount of air pollutant in each forest type} Absorbed amount of each air pollutant calculated from absorption rates were the highest in mixed forest with deciduous broad and evergreen coniferous about $9.57 \mathrm{t} \mathrm{SO}_{2} /$ year, $120.55 \mathrm{t} \mathrm{O}_{3} /$ year, and $26.76 \mathrm{t} \mathrm{NO}_{2} /$ year, respectively, in Gongju-city (Fig. 3). Also, it was the secondly high in deciduous broad-leaved forest about $6.61 \mathrm{t} \mathrm{SO}_{2} /$ year, $83.28 \mathrm{t} \mathrm{O}_{3} /$ year, and $18.49 \mathrm{t} \mathrm{NO}_{2} /$ year and was $4.38 \mathrm{t} \mathrm{SO}_{2} /$ year, $55.13 \mathrm{t} \mathrm{O}_{3} /$ year, and $12.24 \mathrm{t} \mathrm{NO}_{2} /$ year in evergreen coniferous. And it was 0.12 t SO $2 /$ year, $1.44 \mathrm{t} \mathrm{O}_{3} /$ year, and $0.33 \mathrm{t} \mathrm{NO}_{2}$ /year in mixed forest with deciduous broad and coniferous; 0.08 t SO 2 /year, $0.95 \mathrm{t} \mathrm{O}_{3} /$ year, and $0.21 \mathrm{t}$ $\mathrm{NO}_{2}$ /year in deciduous coniferous; $0.03 \mathrm{t} \mathrm{SO}_{2}$ /year, $0.43 \mathrm{t}$ $\mathrm{O}_{3} /$ year, and $0.10 \mathrm{t} \mathrm{NO}_{2} /$ year in mixed forest with deciduous and evergreen coniferous; and $0.01 \mathrm{t} \mathrm{SO}_{2}$ /year, $0.17 \mathrm{t}$ $\mathrm{O}_{3}$ /year, and $0.04 \mathrm{t} \mathrm{NO}_{2}$ /year in evergreen broad forest. Consequently, total amount of air pollutant absorbed by forest in Gongju-city was $261.96 \mathrm{t} \mathrm{O}_{3} /$ year, $58.17 \mathrm{t} \mathrm{NO}_{2} /$ year, and $20.80 \mathrm{t} \mathrm{SO}_{2} /$ year (Table 4 ).

\section{$\mathrm{CO}_{2}$ absorption and $\mathrm{O}_{2}$ production}

The most high rate amounts of $\mathrm{CO}_{2}$ absorption and $\mathrm{O}_{2}$ production was shown in deciduous coniferous with $42 \mathrm{t}$ $\mathrm{CO}_{2} /$ ha/year and $30 \mathrm{t} \mathrm{O}_{2} /$ ha/year in Gongju-city. Although it was high in absorbed rate, total amount of air pollutant was shown in deciduous broad forest because of having broad area in study area. Also, it was $32 \mathrm{t}$ $\mathrm{CO}_{2}$ /ha/year and $23 \mathrm{t} \mathrm{O}_{2}$ /ha/year in pure forest of evergreen coniferous and $20 \mathrm{t} \mathrm{CO}_{2} /$ ha/year and $15 \mathrm{t} \mathrm{O}_{2} /$ ha/ year in deciduous and evergreen broad leaves forest, respectively (Table 5).

Mixed forest with deciduous and evergreen coniferous was estimated with $37 \mathrm{t} \mathrm{CO}_{2} /$ ha/year and $27 \mathrm{t} \mathrm{O}_{2} / \mathrm{ha} /$ year, and that was the highest value among the mixed

Table 3 Absorption rates of air pollutant (Arpa) per unit area per year in each forest type in Gongju-city

\begin{tabular}{llll}
\hline Forest & \multicolumn{2}{l}{ Arpa (kg/ha/year) } & \\
\cline { 2 - 4 } types & $\mathrm{SO}_{2}$ & $\mathrm{O}_{3}$ & $\mathrm{NO}_{2}$ \\
\hline $\mathrm{DB}$ & 0.47 & 5.95 & 1.32 \\
EGN & 1.18 & 14.87 & 3.30 \\
DN & 0.98 & 12.30 & 2.73 \\
DN/EGN & 1.08 & 13.58 & 3.01 \\
DB/EGN & 0.83 & 10.42 & 2.31 \\
DB/DN & 0.76 & 9.35 & 2.12 \\
EGN & 0.74 & 9.34 & 2.07 \\
\hline DBd
\end{tabular}

$D B$ deciduous broad, $E C$ Evergreen coniferous, $D C$ deciduous coniferous, $D E C$ deciduous \& evergreen coniferous, DBE deciduous broad \& evergreen coniferous, $D B C$ deciduous broad \& coniferous, $E B$ evergreen broad

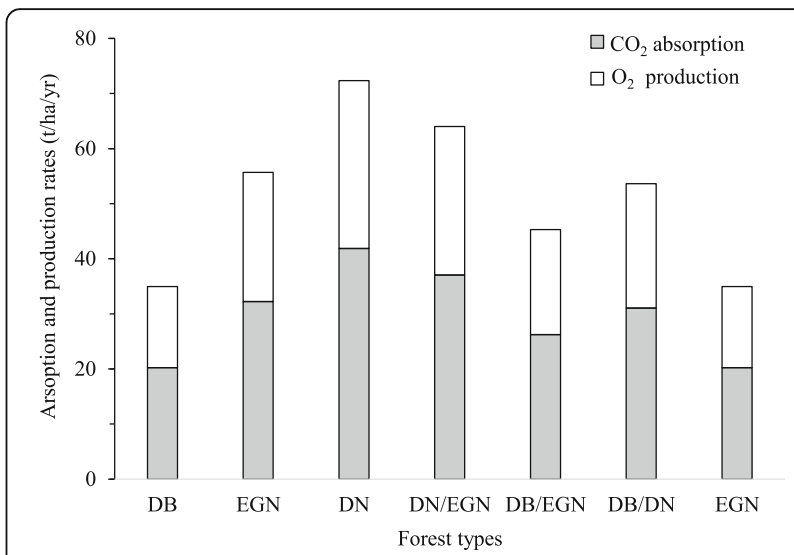

Fig. 3 Absorption rate of $\mathrm{CO}_{2}$ and $\mathrm{O}_{2}$ per unit area per year calculated from net primary production in each forest type in Gongju-city

forest. And it was calculated with $31 \mathrm{t} \mathrm{CO}_{2} / \mathrm{ha}$ /year and $23 \mathrm{t} \mathrm{O}_{2} /$ ha/year in mixed forest with deciduous broad and coniferous and $26 \mathrm{t} \mathrm{CO}_{2} /$ ha/year and $19 \mathrm{t} \mathrm{O}_{2} /$ ha/ year in mixed forest deciduous broad and evergreen coniferous. Total amounts of $\mathrm{CO}_{2}$ absorption and $\mathrm{O}_{2}$ production calculated from these data were $716,045 \mathrm{t}$ $\mathrm{CO}_{2} /$ year and 520,760 t $\mathrm{O}_{2} /$ year in all forest vegetation in Gongju-city.

\section{Conclusions}

In this study, we evaluated the absorption ability of air pollutant in 2014 on forest in Gongju-city area. Gongjucity has the broad mountain area about $70.3 \%$, and area of deciduous broad-leaved forest was established the broadest with $47.4 \%$ of genus Quercus. Pg was calculated about average $18.2 \mathrm{t} /$ ha/year ranged from 25.1 to $10.0 \mathrm{t} /$ ha/year. The mean sequestration amount of each air pollutant per unit area per year assessed from $\mathrm{Pg}$ and $C_{\mathrm{gas}}$ was the highest with $75.81 \mathrm{~kg} / \mathrm{ha} /$ year in $\mathrm{O}_{3}$ and was 16.87 and $6.04 \mathrm{~kg} / \mathrm{ha} /$ year in $\mathrm{NO}_{2}$ and $\mathrm{SO}_{2}$, respectively.

Table 4 Absorbed amount of air pollutant in each forest type in Gongju-city

\begin{tabular}{llll}
\hline \multirow{2}{*}{$\begin{array}{l}\text { Forest } \\
\text { types }\end{array}$} & \multicolumn{3}{l}{ Amount of absorption (t/year) } \\
\cline { 2 - 4 } & $\mathrm{SO}_{2}$ & $\mathrm{O}_{3}$ & $\mathrm{NO}_{2}$ \\
\hline $\mathrm{DB}$ & 6.61 & 83.28 & 18.49 \\
$\mathrm{EC}$ & 4.38 & 55.13 & 12.24 \\
$\mathrm{DC}$ & 0.08 & 0.95 & 0.21 \\
DEC & 0.03 & 0.43 & 0.10 \\
DBE & 9.57 & 120.55 & 26.76 \\
DBC & 0.12 & 1.44 & 0.33 \\
EB & 0.01 & 0.17 & 0.04 \\
\hline $\mathrm{DB}$
\end{tabular}

$D B$ deciduous broad, $E C$ Evergreen coniferous, $D C$ deciduous coniferous, $D E C$ deciduous \& evergreen coniferous, $D B E$ deciduous broad \& evergreen coniferous, $D B C$ deciduous broad \& coniferous, $E B$ evergreen broad 
Table 5 Absorption of $\mathrm{CO}_{2}$ and production of $\mathrm{O}_{2}$ per year calculated from net primary production in each forest type in Gongju-city

\begin{tabular}{lll}
\hline Forest & \multicolumn{2}{l}{ Absorption and production } \\
\cline { 2 - 3 } & $\left(\mathrm{tCO}_{2} /\right.$ year $)$ & $\left(\mathrm{tO}_{2} /\right.$ year $)$ \\
\hline DB & $283,515.8$ & $206,193.3$ \\
EC & $119,453.3$ & $86,875.1$ \\
DC & 3239.2 & 2355.7 \\
DEC & 1187.4 & 863.5 \\
DBE & $303,494.8$ & $220,723.5$ \\
DBC & 4787.8 & 3482.1 \\
EB & 366.7 & 266.7 \\
Total & 716,045 & 520,760
\end{tabular}

$D B$ deciduous broad, $E C$ Evergreen coniferous, $D C$ deciduous coniferous, $D E C$ deciduous \& evergreen coniferous, $D B E$ deciduous broad \& evergreen coniferous, $D B C$ deciduous broad \& coniferous, $E B$ evergreen broad

Absorption rates of $\mathrm{O}_{3}, \mathrm{NO}_{2}$, and $\mathrm{SO}_{2}$ were the highest in evergreen coniferous forest about $14.87 \mathrm{kgO}_{3} /$ ha/year, $3.30 \mathrm{kgNO}_{2} /$ ha/year, and $1.18 \mathrm{kgSO}_{2} /$ ha/year, and the lowest were $5.95 \mathrm{kgO}_{3} /$ ha/year, $1.32 \mathrm{kgNO}_{2} /$ ha/year, and $0.47 \mathrm{kgSO}_{2} /$ ha/year in deciduous broad forest.

In conclusion, it was evaluated that Japanese model is suitable for estimating air pollutants in Japan to Korean vegetation. However, in Korea, there is a very limited basic data needed to assess the ability of forests in absorption of air pollutants. In this study, the accuracy of the calculated values is not high because the basic data of trees with similar life form are used in evaluation. Therefore, in order to accurately assess the value of various service functions performed by the ecosystem, basic data, such as vegetation condition, $\mathrm{Pg}, \mathrm{Pn}$, and $\mathrm{Pn} / \mathrm{Pg}$ for major vegetation, should be obtained as soon as possible. Also, correlation functions between the absorption rates of air pollutants and photosynthesis for the major dominant plants, such as P. densiflora, Q. mongolica, and $Q$. serrata, should be urgently needed. These functional regressions are one of the key factors which are to control absorption capacity of ecosystem.

\section{Acknowledgements}

This study was supported by the National Institute of Ecology in 2016, Republic of Korea.

\section{Funding}

This study was conducted with the support of the National Institute of Ecology, Korea.

\section{Availability of data and materials}

Not applicable

\section{Authors' contributions}

All authors conducted a survey together during the study period. EJY and JSH wrote the manuscript. LJS participated in the design of the study and examined the manuscript. All authors read and approved the final manuscript.
Ethics approval and consent to participate

Not applicable

\section{Consent for publication}

Not applicable

\section{Competing interests}

The authors declare that they have no competing interests.

\section{Publisher's Note}

Springer Nature remains neutral with regard to jurisdictional claims in published maps and institutional affiliations.

Received: 21 August 2017 Accepted: 22 November 2017

Published online: 06 December 2017

\section{References}

Boumans, R., Costanzs, R., Farley, J., Wilson, M. A., Portela, R., Rotmans, J., Villa, F., \& Grasso, M. (2002). Modeling the dynamics of the integrated earth system and the value of global ecosystem services using the GUMBO model. Ecological Economic, 41, 529-560.

Costanza, R., D'Arge, R., de Groot, R. S., Farber, S., Grasso, M., Hannon, B., Limburg, K., Naeem, S., O'Neill, R. V., Paruelo, J., Raskin, R. G., Sutton, P., \& van den Belt, M. (1997). The value of world's ecosystem services and natural capital. Nature, 387, 253-260.

Environmental Restoration and Conservation Agency (2014). Plantation manual for air purification (in Japanese).

Griffin, R., Dabdub, D., \& Seinfeld, J. (2002). Secondary organic aerosol 1. Atmospheric chemical mechanism for production of molecular constituents. Journal of Geophysical Research, 92, 1-36.

Kang, N. (2010). A study on carbon storage in aboveground, root, and fine root of major afforestation species of Korea. Doctorial paper of Chungnam University.

Kim, J., G. Kim, R. Kim, H. Yun, S. Lee, H, Chei, J. Kim and C. Park (2010). A study on public assessment of forest. Korea Forest Research Institute Report 10-26.

Kim, J., Kim, R., Yoon, H., Lee, S., Choi, H., Kim, J., Park, C., \& Kim, K. (2012). Valuation of nonmarket forest resources. Outdoor Recreation Management, 16(4), 9-18.

Korea Forest Service. (2016). Basic statistics of forest. Statistical Yearbook of Forest, 14

Korean Forest Affair (2000). Sustainable forest management.

Korean Forest Service (2016). Report of basic assessment of public function in Forest in 2014.

Kweon, S., Park, Y., \& Kim, E. (2008). Study on forest functions classification using GIS-Chunyang National Forest Management Planning. Journal of Korean Geographic Information, 11(4), 10-21.

Lee, D. (2002). Ecology of Korea. In the 8th Intecol international congress of ecology 19-46.

Lee, J., Cho, K., Jeon, Y., Kim, J., Lim, Y., Lee, K., \& Lee, I. (2017). Characteristics and distribution of terpenes in South Korean forests. Journal of Ecology and Environment, 41(5), 132-141.

Lee, J., Ju, H., \& No, J. (2010). Research on priority of forest values based on AHP. The Journal of Korean Policy Studies, 10(3), 301-317.

Millennium Ecosystem Assessment. (2005). Ecosystems and human well-being. Millennium ecosystem assessment (MA). Washington DC: Island Press.

Ministry of Environment (2014). Air Korea (http://www.airkorea.or.kr/eng/index).

Miyake, H. (1990). Evaluation of atmospheric purification function of green space based on plant productivity. Japan Ministry of Education「Human and Environment」Research Report 038-N31, 1530.

Nelson, E., Mendoza, G., Regetz, J., Polasky, S., Tallis, H., Cameron, D. R., Chan, K. M. A., Daily, G. C., Goldstein, J., Kareiva, P. M., Lonsdorf, E., Naidoo, R., Ricketts, T. H., \& Shaw, M. R. (2009). Modeling multiple ecosystem services, biodiversity conservation, commodity production, and tradeoffs at landscape scales. Front Ecological Environment, 7(4), 11.

Ogawa, W. (1992). In Japanese title. Saitamakenkougaisenta Research Report 19.33-42.

Shu, S., Yu, R., Lee, G., \& An, G. (2006). Application of GIS to evaluate forest functions-focused on Cheonnam National University Experiment Forest. Master paper in Cheonnam University, 14(2), 45-54.

Song, C. I. (2015). Assessment of ecosystem functions and services for air purification of forest. The Degree of master of science in Korea University. 
Sugahara, K. and I. Aiga (1987). Studies on the role of vegetation as a sink of air pollutants. Research Report from National Institute for Environmental Studies, Japan 108, 1-260,

Totsuka, T., \& Miyake, H. (1991). Atmospheric purification of vegetation. Journal of Japan Society of Air Pollution, 26(4), 71-80.

Yun, C., Kim, H., Lee, B., Shin, J., Yang, H., \& Lim, J. (2011). Characteristic community type classification of forest vegetation in South Korea. Journal of Korean Forest Society, 100, 504-521.

Submit your next manuscript to BioMed Central and we will help you at every step:

- We accept pre-submission inquiries

- Our selector tool helps you to find the most relevant journal

- We provide round the clock customer support

- Convenient online submission

- Thorough peer review

- Inclusion in PubMed and all major indexing services

- Maximum visibility for your research

Submit your manuscript at www.biomedcentral.com/submit 